OLENA STEPANENKO, orcid.org/0000-0003-0887-5808 Candidate of Philological Sciences, Associate Professor at the Department of Social and Humanitarian Education Communal Institution of Higher Education "Dnipro Academy of Continuing Education" of Dnipropetrovsk Regional Council (Dnipro,Ukraine) olena.step@ukr.net

Liliya PRYIMAK, orcid.org/0000-0003-1683-271X Candidate of Philological Sciences, Associate Professor at the Department of Foreign Languages and Country Studies Vasyl Stefanyk Precarpathian National University (Ivano-Frankivsk, Ukraine) liliyaklid1@ukr.net

Iryna SEMENYSHYNA, orcid.org/0000-0001-9300-8914

Candidate of Physical and Mathematical Sciences, Associate Professor of the Department of Mathematics, Informatics and Academic Writing of State Agrarian and Engineering University in Podilia (Kamianets-Podilsky, Ukraine) isemenisina@gmail.com

\section{INDEPENDENT WORK AS A MEANS OF DEVELOPING THE PROFESSIONAL COMPETENCIES OF STUDENTS}

The academic paper defines the role and importance of independent work in the process of self-development of a student's personality while studying at higher education institutions (HEIs), in particular, the acquisition of professional competencies. It has been noted that currently the educational process is directed towards the formation of general abilities of the individual to independently acquire knowledge, the formation of life and professional competencies, as well as, the most important oneinformation competency. The approach used by the HEIs to correlate the volume of individual components of educational programs (curricula) with the actual workload of the degree-seeking students (including independent work) has been considered. Nowadays, it is not so much specific professional skills and abilities that are becoming especially important, but the general ability to acquire knowledge, the ability to independently use it to solve a large number of complex problems, analyze information, highlight the essential issues, think critically. The purpose of the educational process is the acquisition of key competencies by the future specialist, manifested in the ability to independently solve problems of a different nature based on the use of information, communication, social and legal principles of personality behaviour in the civil society. The effective directions of activating this process have been highlighted. Particular attention is drawn to the fact that independent work is a process of student's independent activity aimed at the development of his personality. It has been proven that the educational process with a sophisticated system of students' independent work creates a basis for the development of activities, ensuring a consistent transition of learning processes into self-education. The analysis of pedagogical technologies has shown that modular training in this direction has a number of advantages, in particular: mobility, flexibility, adaptability; the possibility of choosing an individual educational trajectory with its subsequent correction and improvement through the choice of individual methods of learning the material; creating a positive motivation for learning and self-education, a positive climate of cooperation and partnership. A modular teaching technology has been proposed, which determines the availability of the most important features necessary for students' independent work, contributing to the development of professional competencies.

Key words: independent work, self-education, self-improvement, competency, competence, information competence.

Постановка проблеми. Сьогодення окреслило актуальність проблеми самостійного навчання, зокрема у віртуальному середовищі. Сучасний освітній простір потребує розвитку навичок самостійної навчальної діяльності, креативного підходу до оволодіння знаннями, формування критичного мислення, дослідницької культури, активного саморозвитку особистості.

Саморозвиток - це особлива розумова діяльність індивідуума, в результаті якої змінюється його особистість. Становлення іï як цілісної сис- теми можливе лише в єдності наступних складників: самопізнання, самооцінка, самоконтроль, саморегуляція та самовдосконалення.

Система освіти відіграє велику роль у процесі саморозвитку. Об'єктивно вища освіта має в собі потенціал для стимулювання особистісного зростання студентів, оскільки є цілеспрямованою системою забезпечення саморозвитку всіх учасників педагогічного процесу.

Водночас постає питання реалізації цілей освітньої системи ЗВО, для чого необхідно 
модернізувати саму систему навчання, зокрема в частині розроблення ефективних методів самостійного здобуття знань, а також сприяння саморозвитку студентів. А саме створення педагогічних умов, як для засвоєння навчального матеріалу під час аудиторних занять, так і для самоосвіти студентів. Загальновідомо, що самостійна робота студентів (СРС) є невід’ємною частиною навчання у ЗВО, оскільки сприяє поглибленому засвоєнню знань. СРС є особливою вищою формою навчальної діяльності, що зумовлюється індивідуальними психологічними особливостями здобувачів освіти. Однак важливо не тільки дотриматися вимог модернізації змісту освіти та застосування інноваційних методів навчання, але і забезпечити виконання низки умов, що визначають саму можливість успішного розвитку професійних компетенцій під час самостійної роботи студентів сучасної вищої школи.

Аналіз досліджень і публікацій. Проблема організації самостійної роботи студентів висвітлюється у багатьох наукових працях сьогодення (Гончарова, 2019; Малихін, 2009; Сушко, Колодій, 2018; Тищенко). Всебічний аналіз напрямів визначення самостійної роботи і самостійної діяльності студентів в освітньому процесі свідчить про те, що сьогодні відсутнє єдине тлумачення ролі, місця та методики організації самостійної діяльності. Більшість сучасних вчених говорить про неоднозначність цього процесу, відсутність універсального, тобто прийнятного для всіх, визначення поняття самостійної роботи студентів (Баліцька, 2011; Ягельська, 2005). На нашу думку, це пояснюється багатофакторністю, складністю спостереження, а також залежністю феномена СРС від індивідуальних психологічних особливостей індивідуума.

Візьмемо за робочий варіант визначення, запропоноване Н. В. Ягельською, згідно з яким самостійна робота - це форма організації і реалізації навчально-пізнавальної діяльності студентів, яку спрямовує і контролює викладач або сам студент відповідно до програми навчання та індивідуальних потреб на аудиторних заняттях або у вільний час з метою оволодіння професійними знаннями, навичками й уміннями та для самовдосконалення (Ягельська, 2005).

Здебільшого дослідники (Болюбаш, 2009; Жалдак, 2011; Жук, Соколюк, Дементієвська, Пінчук, 2012) вважають, що СРС сприяє формуванню наступних факторів розвитку особистості: раціональна організація розумової праці, під час якої відбувається актуалізація зусиль на розумінні, запам'ятовуванні та засвоєнні навчального матеріалу; вироблення адекватної самооцінки; схильність до саморозвитку. Хоча забезпечення самостійної роботи ЗВО є актуальним напрямом у педагогіці, але варто більше уваги приділяти саме розвитку професійних компетенцій в умовах іiі організації.

Метою статті $\epsilon$ визначення впливу самостійної роботи на процес саморозвитку особистості студента під час навчання у ЗВО, зокрема на формування професійних компетенцій, виокремлення пріоритетних.

Виклад основного матеріалу. Однією 3 основних цілей закладів вищої освіти є підготовка спеціалістів, які здатні вести конкурентоспроможну діяльність в інформаційному суспільстві. Віртуальний освітній простір, який відображає взаємозв'язок всіх сфер особистості - інтелектуальної, емоційної, ціннісної, поведінкової, останній часом став пріоритетним засобом здобуття знань.

Сучасне суспільство ставить вимоги щодо підготовки освітніми установами конкурентоспроможних професіоналів із високим рівнем компетентності, здатних швидко реагувати на якісні зміни як у професійній, так і суспільній сфері, які готові до постійного професійного розвитку. Це пов'язано з орієнтацією навчального процесу на розвиток компетенцій у майбутніх фахівців, побудованих на основі навчання, яке формує насамперед професійні компетенції.

У цій роботі щодо професійної компетенції і компетенції загалом використовуються терміни «компетентність» $\mathrm{i}$ «компетенція». Вони розглядаються як нерозривно пов'язані поняття, оскільки компетенції, які мають набір знань і навичок, розуміються як компоненти компетенції і визначають iii рівень. Саме через важливу роль професійних компетенцій у формуванні спеціаліста організація високоякісного самостійного навчання має бути пріоритетом для будь-якого навчального закладу чи навчальної організації. Результативність має відображати фактичні досягнення наприкінці процесу навчання та їх відповідність нормативним вимогам і очікуванням громадськості, а якість вже проведеного навчання оцінюватиметься за рівнем компетенцій, набутих внаслідок цього та продемонстрованих у професійному середовищі під час виконання роботи.

Звернемося до аналізу підходів до визначення ролі самостійної роботи у формуванні системи ключових компетентностей особистості.

На сучасному етапі розвитку українського суспільства відбувається реформування освіти, робиться спроба реорганізації освітніх моделей. Науковці, педагоги, методисти прагнуть оновлення освіти, наполягаючи на відмові від репродукції знань, оскільки сама по собі інформація 
втрачає вагу, якщо немає прикладного характеру, тоді як добування інформації стало пріоритетним у діяльності людини. Втрачається необхідність перевантаження певними знаннями, зростає потреба вміння користуватися ними. Однією 3 причин відставання вищої школи від запитів сьогодення $є$ недостатньо обгрунтований підхід до визначення, якою має бути інформаційно-компетентна особистість, якими якостями повинен володіти студент для того, щоб успішно виконувати завдання, які висуває перед нами сучасне інформаційне суспільство. Нині особливо важливими стають не стільки конкретні професійні вміння та навички, скільки загальні здібності набувати знань, уміння самостійно використовувати їх для вирішення великої кількості складних задач, аналізувати інформацію, виділяти суттєве, мислити критично.

Актуальна на сьогоднішній день проблема інформаційної компетентності бере початок у концепції інформаційного суспільства, що наполягає на визнанні людством пріоритету інформації, що кардинальним чином змінює всю структуру соціальної діяльності, включаючи систему освіти.

У сучасній педагогічній спільноті актуальним $€$ розгляд проблеми невідповідності вимог до компетентності спеціаліста чи студента та існуючої моделі освіти, тобто в межах так званого компетентнісного підходу, що висуває на перше місце не поінформованість студента, не «багаж знань», накопичених у процесі фахової підготовки у навчальному закладі, а вміння самостійно розв'язувати проблеми, що виникають у різних видах діяльності, у сферах етичних, соціальних, правових, професійних, особистих взаємовідносин. 3 огляду на дуже швидке старіння інформації у сучасному суспільстві запропонований підхід має на увазі такий зміст освіти, який не зводиться до знаннєво орієнтованого компонента, а передбачає цілісний досвід вирішення життєвих проблем, виконання ключових (тобто тих, що належать до багатьох соціальних сфер) функцій, соціальних ролей, компетенцій (Москалик, 2014).

Термін «компетентність» є перекладом англійського слова "competence", що означає "the ability to do something well; a skill that you need in a particular job or for a particular task" (тобто здатність робити щось добре; уміння, необхідні для виконання певної роботи чи завдання) (Великий тлумачний словник, 2004). Словник іншомовних слів надає таке значення компетентності 3 посиланням на прикметник «компетентний» 1) володіння компетенцією (в значенні «коло повноважень»); 2) володіння знаннями, що дозво- ляють мати уявлення про щось (Oxford Advanced Lerner's Dictionary, 2000).

Останнім часом можна простежити тенденцію до виокремлення важливості в процесі отримання освіти, самостійної роботи та набутого практичного досвіду студента. Отже, компетентність дослідниками розглядається не стільки як знання, уміння, навички, скільки як досвід людини. На думку В. Нетреби та Н. Денисової, компетентність - це загальна здатність, що базується на знаннях, досвіді, цінностях, здібностях, набутих завдяки навчанню, зокрема самонавчанню. Компетентність вивчають як складний синтез когнітивного, предметно-практичного та особистісного досвіду, що існує у різних формах: як рівень умілості, як спосіб особистісної самореалізації (звичка, спосіб життєдіяльності, захоплення), як деякий результат саморозвитку індивіда або форми проявлення здібності (Нетреба, 2005).

Таким чином, можемо зробити висновок, що компетентність - це особистісна характеристика, яка означає здатність самостійно вирішувати життєві проблеми і завдання в конкретних життєвих ситуаціях, уміти концентруватися, мобільно застосовувати знання, вміння, досвід та творчий потенціал відповідно до ситуації, адекватно до соціальних, культурних та економічних умов у суспільстві.

Метою освітнього процесу є набуття майбутнім фахівцем ключових компетентностей, що виявляються у здібності самостійно вирішувати завдання різного характеру на основі використання інформації, комунікації, соціально-правових основ поведінки особистості в громадянському суспільстві. 3 огляду на це найцікавішим є погляд українського автора Г. К. Селевка щодо визначення ключових компетентностей (Селевко, 2005):

- комунікативна - вміння вступати в комунікацію з метою бути зрозумілим, володіння уміннями спілкування;

- автономізаційна - вміння саморозвитку i самопрезентації, здатність до самовизначення, самоосвіти, конкурентоздатності;

- соціальна - вміння жити і працювати разом 3 іншими людьми у трудовому колективі, в єдиній команді;

- продуктивна - вміння працювати і заробляти, здатність до створення власного продукту, вміння приймати рішення та відповідати за них;

- моральна - готовність, здатність і потреба жити за загальнолюдськими моральними законами;

- інформаційна - володіння інформаційними технологіями, вміння працювати зі всіма видами інформації. 
За визначенням Г. К. Селевка, інформаційна компетентність - це ключова суперкомпетентність людини XXI ст., важливий інструмент майбутньої професійної діяльності теперішніх учнів і студентів (Селевко, 2005).

Отже, як бачимо із вищезазначеного, саме поняття «інформаційна компетентність» не зводиться до простої кваліфікації, що враховує актуальні на даний час навички роботи із засобами зберігання та передачі інформації (як традиційними, так і електронними). Вона включає досвід роботи із самою інформацією, уміння здійснювати пошук, критично сприймати, оцінювати та самостійно обробляти здобуту інформацію.

Таким чином, інформаційно-комунікаційна компетентність - це багатогранне інтегративне утворення особистості, що являє собою сукупність умінь та навичок роботи 3 інформацією у традиційній та електронній формі, здатність до роботи 3 комп'ютерною технікою, здатність до цілеспрямованого пошуку та до переробки i викладення здобутої інформації, заснована на інтелектуальному та творчому потенціалі, особистісних якостях, ціннісних орієнтаціях та досвіді.

Інформаційно-комунікаційна компетентність у самостійній роботі тісно пов'язана з використанням універсальних процедур пошуку, опрацюванням і представленням інформації на грунті відповідної системи понять, принципів і законів наукового пізнання, відображенням об'єктивної реальності і систем фактичного матеріалу (бази знань, даних, пошуку тощо) (Баловсяк, 2006).

Отже, проаналізоване вище доводить, що у сучасному інформаційному суспільстві, коли старіння інформації відбувається значно швидше, ніж завершується цикл навчання у вищій школі, здобуття інформації стає пріоритетною діяльністю людини, що охоплює всі сфери іiї життя професійну, соціальну, побутову. Важливим у цій ситуації є спрямування освітнього процесу на формування загальних здібностей індивідуума до самостійного здобуття знань, формування життєвих та професійних компетентностей, а також найголовнішої з них - інформаційної.

Так, стосовно відповідності системи навчання вимогам європейського законодавства та законодавства України, на наш погляд, необхідно виокремити наступне. Вимога високої якості навчання продиктована сучасним баченням європейського суспільства, заснованим на високоосвічених i добре підготовлених людських ресурсах, здатних адекватно реагувати на зміни в оточуючому середовищі, що відбуваються динамічно. Значна залежність між набутими знаннями та навичками і можливостями знайти правильне (професійно компетентне) рішення вимагає, щоб освіта була орієнтована на формування професійних компетенцій. Результати визначаються 3 точки зору знань, умінь і навичок, заснованих на компетенціях, які регламентує Національний стандарт освіти та Європейська рамка кваліфікацій (Вища освіта України, 2004).

Процес навчання має забезпечувати високий рівень професійних компетенцій, для чого він має включати придбання наступних груп знань та навичок: знання та навички в галузі суспільних, організаційних та управлінських знань та навичок, прикладні знання та навички та спеціальні знання та навички.

Велике значення для правильності вибору навчального контенту має забезпечення взаємодії між викладачами та персоналом ЗВО і студентами, під час якої здобувачі освіти дізнаються, що їм потрібно знати і що вони можуть зробити для майбутньої реалізації своїх знань у професії, до здобуття якої готуються.

Таким чином, самостійна робота студентів це форма організації їх навчальної діяльності, що здійснюється під прямим або непрямим керівництвом викладача.

Далі важливо окреслити ефективні напрями вдосконалення СРС. Піднімаючи питання ролі й місця самостійної роботи студентів у системі підготовки фахівця, необхідно зазначити, що організована самостійна діяльність студентів у позанавчальний час може виступати основою для формування основних умінь самоосвітньої діяльності.

На сучасному етапі модернізації системи вищої освіти вченими-педагогами пропонується безліч методик, спрямованих на різнобічний розвиток фахівця. Попри численність й іноді суперечливість цих підходів, більшість 3 них схожі в тому, що самостійна робота студента $є$ засобом реалізації основної освітньої програми, а також володіє розвиваючою і виховною функцією.

Звертаємо увагу на те, що самостійна робота $\epsilon$ процесом самостійної діяльності студента, спрямованої на розвиток його особистості. При цьому необхідно розглядати феномен 3 двох взаємопов' язаних сторін: постановки навчальних завдань (завдань) і організації (самостійно або під керівництвом викладача) діяльності студента під час виконання цього завдання.

Важливо розуміти, що самостійна робота студента в межах освітнього процесу - це не тільки його самостійна підготовка до занять, заліків, іспитів або інших видів занять, це діяльність, спрямована на саморозвиток і самоосвіту 
особистості, що служить основою для самоосвітньої діяльності.

Крім того, освітнє середовище 3ВО, що забезпечує ефективну СРС, повинно забезпечувати своєчасне оновлення джерел інформації (підручників, навчальних посібників), методичних і контролюючих матеріалів, додаткових матеріалів, що забезпечують самоосвітню діяльність студентів.

Очевидно, що за такої постановки питання необхідно вирішення двох основних питань: вибір адекватних методів і технологій організації самостійної діяльності (роботи) студентів; методичне забезпечення самостійної діяльності (роботи) студентів.

Розглянемо, який підхід використовують ЗВО для співвідношення обсягу окремих освітніх компонентів освітніх програм у кредитах Свропейської кредитно-трансферної системи (СКТС) iз фактичним навантаженням здобувачів вищої освіти (включно із самостійною роботою).

Навчальне навантаження здобувачів освіти та співвідношення годин аудиторних занять і самостійної роботи визначається Положенням про організацію освітнього процесу вищого учбового закладу. Обсяги освітніх компонентів у кредитах ЄКТС визначаються освітніми навчальними програмами (ОНП). На підставі ОНП створюється навчальний план ЗВО, у якому відображено перелік та обсяги обов'язкових та вибіркових навчальних дисциплін, практик, загальний бюджет навчального часу, його розподіл на аудиторний час за окремими формами занять та час, відведений на самостійну роботу. Обсяг одного кредиту ЄКТС становить 30 годин, які включають аудиторну та самостійну роботу.

Самостійна робота складає від 50 до $80 \%$ загального обсягу навчального часу, відведеного на вивчення конкретної дисципліни. Загальний обсяг ОНП становить 45 кредитів СКТС, з яких обсяг аудиторної роботи - 29\%, а самостійної роботи $71 \%$, що регламентується Положенням про організацію освітнього процесу. Середня кількість ауди- торних годин на один кредит становить - 9 годин, тоді як 21 година відводиться на самостійну роботу. Для заочної форми навчання обсяги аудиторних годин (лекцій, практичних, семінарських, лабораторних занять) за дисциплінами дорівнюють приблизно шостій частині їх обсягів для денної форми навчання та $є$ парними числами.

Основні форми самостійної роботи студентів наведено у табл. 1.

Виходячи із вищезазначеного, окреслимо основні напрями активізації СРС $з$ метою розвитку професійних компетенцій:

- постановка завдань і підготовка навчального матеріалу: після формулювання умови задачі відбувається контроль ступеня розуміння завдання 3 подальшою підготовкою необхідного навчального матеріалу, який допомагає студенту у вирішенні цього питання, іншими словами, проводиться індивідуальний підбір необхідного матеріалу з урахуванням індивідуального рівня готовності студента;

- організація діяльності студента і викладача: відбувається акцентування цілей і завдань діяльності студента, індивідуалізація навчання з обов'язковим контролем результату на шляху «видача інформації - контроль - засвоєння інформації»;

- позиція викладача: викладач виконує роль консультанта, радника, мотиватора, який надає джерела інформації, при цьому викладач за допомогою індивідуальних програм виробляє індивідуальну корекцію освітньої програми студента;

- індивідуальний вибір засобів, методів і темпів навчання, з урахуванням індивідуальних психологічних і фізіологічних можливостей;

- контроль: після постановки завдань обов'язково озвучуються критерії оцінки правильності їх вирішення. Завдання мають на меті визначення рівня засвоєння, закріплення засвоєння інформації, діагностування труднощів вивчення матеріалу. Проводиться вхідний контроль (тестування), проміжний і підсумковий;

Таблиця 1

Форми самостійної роботи студентів

\begin{tabular}{|c|c|c|c|}
\hline \multicolumn{2}{|c|}{ Аудиторна } & \multicolumn{2}{|c|}{ Позааудиторна } \\
\hline Колективна & Групова & Олімпіада & Індивідуальна \\
\hline Круглий стіл & Робота в парах & Конкурс & $\begin{array}{c}\text { Робота з навчальною } \\
\text { літературою }\end{array}$ \\
\hline Симпозіум & Робота в малих групах & Факультатив & Розв'язування задач \\
\hline Бесіда & Робота з тьютором & Конференція & $\begin{array}{c}\text { Написання курсових } \\
\text { (диломних) робіт }\end{array}$ \\
\hline Дискусія & \multicolumn{3}{|c|}{ Дослідницька робота } \\
\hline Ділові та ситуативні ігри & \multicolumn{3}{|c|}{ Проєктування } \\
\hline Проблема лекція & \multicolumn{3}{|c|}{ Консультації } \\
\hline
\end{tabular}

Джерело: складено автором на основі (Гончарова, 2019; Малихін, 2009; Тищенко) 
- організація зворотного зв'язку, яка дозволяє проводити корекцію діяльності викладача і студента за результатами контролю. В умовах застосування модульної технології навчання кожна порція інформації (модуль, блок) закінчується контролем із подальшим аналізом результатів, виявленням помилок і корекцією діяльності.

Аналіз педагогічних технологій показує, що модульне навчання у цьому напрямі має низку переваг, зокрема: мобільність, гнучкість, адаптивність; можливість вибору індивідуальної освітньої траєкторії з подальшою іiі корекцією і вдосконаленням за рахунок вибору індивідуальних методик засвоєння матеріалу; створення позитивної мотивації до навчання і самоосвітньої діяльності, позитивного клімату співпраці і партнерства.

Основнимипринципами,щопокладенівоснову модульної технології навчання, які сприяють активізації СРС та розвитку професійних компетенцій, є: переорієнтація освітнього процесу від поточного методу до індивідуальної підготовки; зростання ролі СРС; адаптація програм навчання до кожного студента; надання можливостей застосування нових інформаційних технологій, спеціалізованих програм; оновлення ролі викладача в освітньому процесі, перетворення його на консультанта, який здійснює індивідуальне керівництво самостійною діяльністю студента за допомогою автоматизованого навчального комплексу; впровадження системи безперервного контролю знань (тестування), який дозволяє постійно проводити корекцію навчального процесу.

Перераховані вище особливості модульної технології навчання зумовлюють наявність у ній найбільш важливих для СРС характеристик, що сприяють розвитку професійних компетенцій (рис. 1):

Найбільш важливі для СРС характеристики в умовах модульної технології навчання, що сприяють розвитку професійних компетенцій

постановка глобальних і локальних цілей та завдань, постійне їх уточнення, орієнтація студентів на досягнення конкретного результату конкретного заняття, блоку занять, дисципліни, навчання в цілому

підготовка матеріалу з урахуванням особистого досвіду викладача, вимог до професійних навичок фахівця і цілеспрямована організація освітнього процесу 3 урахуванням індивідуальних психологічних та фізіологічних особливостей i здібностей студентів

ефективність у вирішенні поставлених завдань за рахунок постійного оперативного зворотного зв'язку, розрахунок коефіцієнтів кореляції готовності студента до самоосвітньої діяльності та рівня засвоєння матеріалу і постійна індивідуальна корекція освітньої програми

постійний контроль і оцінка отриманих результатів, контроль рівня засвоєння матеріалу за допомогою проміжного і підсумкового тестувань

спрямованість на досягнення конкретних цілей, які залежать від соціального замовлення, вимог освітніх стандартів, змісту навчання

цілеспрямована побудова освітнього процесу 3 поетапним ускладненням нестандартних завдань і задач, складність яких залежить від індивідуальних здібностей, з подальшою гарантією досягнення необхідного результату

можливість багаторазового відтворення етапів освітнього процесу, можливість його алгоритмізації, вироблення індивідуальних методичних рекомендацій 3 вивчення матеріалу, розв'язування задач і завдань

Рис. 1. Найбільш важливі для СРС характеристики в умовах модульної технології навчання, що сприяють розвитку професійних компетенцій

Джерело: авторська розробка 
Отже, такі можливості дозволяють впевнене застосування модульної технології, що сприяє не лише формуванню навичок самоорганізації і самоконтролю, а й професійних компетентній та передбачає становлення майбутнього фахівця як суб'єкта професійної діяльності, здатного до саморозвитку. Крім того, виявлені особливості і характеристики модульної системи дозволяють зробити висновок про досягнення поставлених цілей у межах освітнього середовища та інтегрованих у нього інформаційних ресурсів і технологій.

Висновки. Узагальнюючи різні підходи до розглянутого феномену самостійної роботи, можна констатувати, що практично всі вчені єдині у визначенні наступних ознак самостійної роботи: наявність завдання, в тому числі й індивідуального; відсутність безпосереднього керуючого впливу на діяльність студента; наявність додаткового часу (в основному у позанавчальний час); непрямий вплив викладача на процес організації самостійної роботи; відсутність контролю з боку викладача на проміжних етапах, тобто наявність контролю лише кінцевого результату.

Під самостійною діяльністю в межах освітнього процесу ми розуміємо цілеспрямований процес навчання, який здійснюється студентом без безпосередньої участі викладача, процес самостійного оволодіння знаннями, вміннями і навичками під час виконання певних завдань. Крім того, ми переконані, що самостійну роботу необхідно розглядати в єдності всіх іiі структурних складників, спрямованих на розвиток професійних компетенцій студентів у період навчання, що своєю чергою вимагає цілеспрямованої організації системи планування i реалізації принципів самоосвітньої діяльності.

3 огляду на це вважаємо за необхідне зробити висновок про те, що самостійна робота студентів як один 3 видів позанавчальної діяльності та засіб розвитку професійних компетенцій повинна бути інтегрована в освітнє середовище ЗВО. Це означає, що в процесі розвитку самоосвітньої діяльності студентів та підготовки їх до самоосвіти та самовдосконалення впродовж усього життя самостійна робота, організована в межах освоєння основної освітньої програми, виступає провідним методом, що забезпечує успішність ії виконання.

Характеристики освітнього середовища, проаналізовані у статті, свідчать про те, що саме модульна технологія спрямована на формування стійких мотивів до навчання і збільшення частки самостійної роботи студента.

Таким чином, освітній процес 3 продуманою системою самостійної роботи студентів створює базу для розвитку самоосвітньої діяльності та забезпечує послідовний перехід процесів навчання в самоосвіту. Не викликає жодних сумнівів, більше того - перевірено практикою, що СРС насамперед $є$ засобом формування професійних компетенцій майбутніх фахівців, а також найголовнішої з них - інформаційної.

\section{СПИСОК ВИКОРИСТАНИХ ДЖЕРЕЛ}

1. Балицька Т. В. Організаційно-педагогічні умови самостійної роботи студентів у процесі кредитно-модульного навчання. Вісник ЛНУ ім. Тараса Шевченка. 2011. № 13(224). Ч. I. С. 53-59.

2. Баловсяк Н. В. Концепція визначення структури інформаційної компетентності фахівця. Мелітополь : МДПУ, 2006.30 с.

3. Болюбаш Я. М. Один з принципів Болонського процесу - мобільність студентів у європейському просторі. Освіта України. 2006. № 1. С. 4.

4. Великий тлумачний словник сучасної української мови / уклад. і голов. ред. В. Т. Бусел, Київ ; Ірпінь : ВТФ «Перун», 2004. 1440 с.

5. Вища освіта України і Болонський процес: навч. посіб. / за ред. В. Г. Кременя. Тернопіль : Богдан, 2004. 384 с.

6. Гончарова $€$. Роль самостійної роботи у процесі формування фахово орієнтованих компетентностей студентів ЗВО України. Педагогічні науки. 2019. № 73. С. 67-71.

7. Жалдак М. І. Система підготовки вчителя до використання інформаційно-комунікаційних технологій в навчальному процесі. Науковий часопис НПУ імені М. П. Драгоманова. 2011. 14 с.

8. Жук Ю. О., Соколюк О. М., Дементієвська Н. П., Пінчук О.П. Організація навчальної діяльності у комп’ютерноорієнтованому навчальному середовищі. Київ : Педагогічна думка, 2012. 128 с.

9. Малихін О. В. Організація самостійної навчальної діяльності студентів вищих педагогічних навчальних закладів : теоретико-методологічний аспект : монографія. Кривий Ріг : Видавничий дім, 2009. 307 с.

10. Москалик Г. Поняття, природа i джерела формування інформаційно-комунікаційного середовища. Гілея: збірник наукових праць. 2013. Випуск 77 (№ 10). С. 149-152.

11. Нетреба В. Компетентності - шлях до оновлення освіти. Київ : Плеяди, 2005. 105 с.

12. Селевко Г. К. Педагогические технологи на основе информационно-коммуникационных средств. Москва : НИИ школьных технологий, 2005. 208 с.

13. Сушко О. В., Колодій О. С. Організація самостійної роботи студентів ЗВО та ії роль у процесі професійної підготовки. Удосконалення освітньо-виховного процесу в вищому навчальному закладі: збірник науково-методичних праць. ТДАТУ. 2018. Вип. 21. С. 27-36.

14. Тищенко О. І. Загальнонаукові засади дослідження поняття професійної компетентності. Oсвіта запорізького краю. URL: http://virtkafedra.ucoz.ua/el_gurnal/pages/vyp10/tishenko.pdf (дата звернення: 13.11.2021). 
15. Ягельська Н. В. Методика організації самостійної роботи студентів з англійської мови з використанням професійного мовного портфеля: автореф. дис. ... канд. пед. наук : 13.00.02. Київський національний лінгвістичний університет. Київ, 2005. 23 с.

16. Oxford Advanced Lerner's Dictionary of Current English. 6th edition. Oxford University Press, 2000. 1568 c.

\section{REFERENCES}

1. Balic'ka T. V. Organizacijno-pedagogichni umovi samostijnoyi roboti studentiv u procesi kreditno-modul'nogo navchannya [Organizational and pedagogical conditions of independent work of students in the process of credit-module training]. Visnik LNU im. Tarasa Shevchenka [Bulletin of LNU. Taras Shevchenko]. 2011. № 13(224). Ch.I. P. 53-59 [in Ukrainian].

2. Balovsiak N. V. Kontseptsiia vyznachennia struktury informatsiinoi kompetentnosti fakhivtsia [The concept of determining the structure of information competence of the specialist]. Melitopol : MDPU, 2006. 30 p. [in Ukrainian].

3. Boliubash Ya. M. Odyn z pryntsypiv Bolonskoho protsesu - mobilnist studentiv u yevropeiskomu prostori [One of the principles of the Bologna Process is the mobility of students in the European space]. Osvita Ukrainy [Education of Ukraine]. 2006. № 1. P. 4. [in Ukrainian].

4. Velykyi tlumachnyi slovnyk suchasnoi ukrainskoi movy [Large explanatory dictionary of the modern Ukrainian language], uklad. i holov. red. V.T. Busel, Kyiv; Irpin: VTF "Perun", 2004. 1440 p. [in Ukrainian].

5. Vyshcha osvita Ukrainy i Bolonskyi protses: navch. posibnyk [Higher Education in Ukraine and the Bologna Process], za red. V. H. Kremenia, Ternopil: Navchalna knyha. Bohdan, 2004. 384 p. [in Ukrainian].

6. Honcharova Ye. Rol samostiinoi roboty u protsesi formuvannia fakhovo oriientovanykh kompetentnostei studentiv ZVO Ukrainy [The role of independent work in the process of forming professionally oriented competencies of students of the Free Economic Zone of Ukraine]. Pedahohichni nauky [Pedagogical sciences]. 2019. № 73. P.67-71 [in Ukrainian].

7. Zhaldak M. I. Systema pidhotovky vchytelia do vykorystannia informatsiino-komunikatsiinykh tekhnolohii $\mathrm{v}$ navchalnomu protsesi [The system of teacher training for the use of information and communication technologies in the educational process]. Naukovyi chasopys NPU imeni M. P. Drahomanova [Scientific Journal of NPU named after MP Drahomanov]. 2011. 14 p. [in Ukrainian].

8. Zhuk Yu. O., Sokoliuk O. M., Dementiievska N. P., Pinchuk O. P. Orhanizatsiia navchalnoi diialnosti u kompiuternooriientovanomu navchalnomu seredovyshchi [Organization of educational activities in a computer-oriented learning environment]. K.: Pedahohichna dumka, 2012. 128 p. [in Ukrainian].

9. Malykhin O.V. Orhanizatsiia samostiinoi navchalnoi diialnosti studentiv vyshchykh pedahohichnykh navchalnykh zakladiv: teoretyko-metodolohichnyi aspekt [Organization of independent educational activity of students of higher pedagogical educational institutions: theoretical and methodological aspect]. Kryvyi Rih : Vydavnychyi dim, 2009. 307 p. [in Ukrainian].

10. Moskalyk H. Poniattia, pryroda i dzherela formuvannia informatsiino-komunikatsiinoho seredovyshcha [The concept, nature and sources of information and communication environment]. Hileia: zbirnyk naukovykh prats [Gilea: a collection of scientific papers]. 2013. Vypusk 77 (№ 10). P. 149-152.

11. Netreba V. Kompetentnosti - shliakh do onovlennia osvity. [Competences are a way to renew education]. K.: Pleiady, 2005. 105 p. [in Ukrainian].

12. Selevko H. K. Pedahohycheskye tekhnolohy na osnove ynformatsyonno-kommunykatsyonnykh sredstv. [Educational technologists based on information and communication means]. M.: NYY shkolnykh tekhnolohyi, 2005. 208 p. [in Russian]

13. Sushko O.V., Kolodii O.S. Orhanizatsiia samostiinoi roboty studentiv ZVO ta yii rol u protsesi profesiinoi pidhotovky [Organization of independent work of freelance students and its role in the process of professional training]. Udoskonalennia osvitno-vykhovnoho protsesu $\mathrm{v}$ vyshchomu navchalnomu zakladi: zbirnyk naukovo-metodychnykh prats [Improving the educational process in higher education]. TDATU. 2018. Vyp. 21. P. 27-36 [in Ukrainian].

14. Tyshchenko O. I. Zahalnonaukovi zasady doslidzhennia poniattia profesiinoi kompetentnosti [General scientific principles of research of the concept of professional competence]. Osvita zaporizkoho kraiu [Education of the Zaporozhye region]. 12 p. Reteved from: http://virtkafedra.ucoz.ua/el_gurnal/pages/vyp10/tishenko.pdf [in Ukrainian].

15. Yahelska N. V. Metodyka orhanizatsii samostiinoi roboty studentiv z anhliiskoi movy z vykorystanniam profesiinoho movnoho portfelia[Methods of organizing independent work of students in English using a professional language portfolio]: avtoref. dys. ... kand. ped. nauk: 13.00.02. Kyivskyi natsionalnyi linhvistychnyi universytet. Kyiv, 2005. 23 p. [in Ukrainian].

16. Oxford Advanced Lerner's Dictionary of Current English. 6th edition. Oxford University Press, 2000. 1568 p. 